Anna Kasafi Perkins*

\title{
Oh, Sufferah Children of Jah: Unpacking the Rastafarian Rejection of Traditional Theodicies
}

https://doi.org/10.1515/opth-2020-0134

received January 23, 2020; accepted August 04, 2020

\begin{abstract}
The article maintains that the theological perspectives of RastafarI continue to be under-researched in the Caribbean context with perhaps more attention being paid to their contributions to the racial, musical and linguistic traditions of the region. In particular, Rasta theodicies are not as clearly articulated as other elements of its belief system even as it is recognised that RastafarI mansions and individual members do not hold homogenous beliefs about many things. The discussion takes as its starting point two prior reflections, "Just Desert or Just Deserts?: God and Suffering in these Perilous Days" (Perkins 2016) and "The Wages of (Sin) is Babylon: Rasta Versus Christian Religious Perspectives of Sin" (Perkins 2012); the former reflection highlights the insufficiency of traditional theodicy to answer the question: "if God is good, why does evil exist?" No one answer can sufficiently do justice to the many dimensions of the question. In that regard, Perkins (2016) argues for attention to the important "answer" that the radical suffering perspective offers to the discussion (Sarah Anderson Rajarigam (2004) too emphasises divine suffering or theopathos, as the response to radical suffering. She frames theopathos not just as an option within theodicy but as an alternative to theodicy, which she derides as "the spoilt child of enlightenment that self-destructively craves for theoretical and philosophical remedies for radical human suffering" (27).). Perkins (2012) explicates a particular Rasta understanding of sin and evil, which are important elements of any theodicy. For Rasta, sin is tri-dimensional - personal, inherited and corporate. Sin in its corporate or social dimension is the most salient as it is moral evil - a rejection of Jah's will - which leads to the oppression of Jah's people.
\end{abstract}

Keywords: theodicy, radical suffering, RastafarI, Jamaica, corporate evil, Babylon

Long hair, freaky ${ }^{1}$ people need not apply/Don’t want no old negah, no Rastafari²/[...] /Equality and justice must stand for all/One day discrimination against Rasta must fall/All you possess you rob from I.

Ras Karbi, "Discrimination.”

Natty dreadlocks haffi face a kinda livin/when Babylon see him naa lef him. ${ }^{3}$

Lieutenant Stitchie, “Natty Dreadlocks.”

1 Freaky may well refer to the fact that Rastas were considered strange, alien. "The brethren themselves are still treated like freaks who just landed from another planet: 'I-n-I are treated in Jamaica as an alien from far outer space, someone that the world did not know were existing' (Leon)” (Owens, Dread: The Rastafarians of Jamaica, 219).

2 English translation: Strange looking and behaving people wearing dreadlocks, i.e., RastafarI, should not apply for work at this establishment. We do not want low class/ill-behaving people or RastafarI.

3 English translation: RastafarI have a difficult life. When policemen see Rastas, they subject them to all kinds of harassment, including beatings, false arrests, etc.

\footnotetext{
* Corresponding author: Anna Kasafi Perkins, Office of the Board for Undergraduate Studies, The University of the West Indies, and St Michael’s Theological College, Kingston, Jamaica, e-mail: Anna.perkins@uwimona.edu.jm
} 
Even though man in his suffering may wish that God would miraculously vanquish all his foes, the ways of the Lord are different: "God a work slow. You expect him to have the thing all ready, to kill all the people them, or chop off Prince Charles." (Jimmy) But instead he bides his time, till all is in readiness.

Joseph Owens, Dread. ${ }^{5}$

In Jamaica, many people describe themselves as "sufferahs," who exist in a condition of "sufferation." Such persons are often among the poor, despised, deprived and often feared, ${ }^{6}$ who lament their condition as one imposed by those in power. Ennis B. Edmonds describes theirs as "the gut-wrenching experiences of suffering and estrangement faced by the underside of Jamaican society."

Perhaps the original self-described sufferahs were the RastafarI, who, from the genesis of their community, in 1930s colonial Jamaica, found themselves among the poorest of the poor and at odds with the state, whose agents, especially the police, regularly victimised and dehumanised them in numerous ways, as is often inveighed against in Reggae and other Jamaican popular music and literature. ${ }^{8}$ The biblical lens through which Rastas interpret their identity and experiences led them to call police "babylon," a designation that now pervades the speech of ordinary Jamaicans. At the time, ordinary Jamaicans poured scorn upon Rasta, and, as Ras Karbi declaims in his hit song, "Discrimination," they were unable to find employment; they were often treated as insane, beaten and shunned. ${ }^{10}$ As such, suffering has marked the identity of Rastafarl ${ }^{11}$ in a fashion that is not sufficiently countenanced, even as Rasta has since become routinised, having largely moved from "pariah to hero" in the Jamaican society, owing to the successes of artistes such as Bob Marley. ${ }^{12}$ (Kitzinger in "Protest and Mysticism" marks the temporary entry of RastafarI into the society which normally rejected them to the 1967 visit of Emperor Haile Selassie.)

Undoubtedly, their anti-systemic stance influenced how they were treated as they refused to conform to the expectations of colonial society; their mistreatment, Blatter argues, has influenced the development of a particular RastafarI theodicy, ${ }^{13}$ that is, response to the challenge of affirming God's goodness, justice and righteousness in the face of evil, great suffering and oppression. ${ }^{14}$ Indeed, Blatter maintains that RastafarI theologies of suffering defy the mainstream society, and, in so doing, challenge traditional notions of theodicy that often support the oppressive status quo. In this regard, Blatter maintains that the Rasta theodicy is unique. While such claims to uniqueness may be difficult or even unnecessary to maintain, Rasta contributions to theologies of suffering may lie in their major contention that suffering is the result of systemic forces ("downpression") ${ }^{15}$ and is, therefore, not adequately explained by traditional theodicies of merited (punishment for sin), or unmerited (redemptive) suffering, which centre on the individual sufferah. Nor is it adequately explained by moral necessity which allows God's goodness to be

\footnotetext{
4 Prince Charles, the heir to the British throne, who is here the representative of the British Empire - Babylon par excellence. 5 Owens, Dread, 190.

6 See Kitzinger, "Protest and Mysticism: The Rastafari Cult of Jamaica,” 240-62.

7 Edmonds, "Dread 'I' in-a-Babylon: Ideological Resistance and Cultural Revitalization," 24.

8 Bob Marley describes the system as vampire that sucks the blood of the sufferers ("Babylon System").

9 See footnote 2 above, which refers to the Lieutenant Stitchie song in which policemen are called "Babylon." That the police are given the designation "Babylon," which is used by Rastas to refer to the global economic system supported by religion and politics, speaks to the identification of the behaviour and posture of the police who were the agents of state with whom they interacted more directly.

10 See Hickling and Griffith, “Clinical Perspectives on the Rastafari Movement,” for cases illustrating attitudes towards Rasta that are racial and class based.

11 Owens, Dread.

12 Broek, "Pariah to Hero."

13 Blatter, "Chant Down Babylon."

14 DeCosmo's, "Religion and Revolution."

15 Rastafarians have created a series of "antithetical words that carry the phonological implications of root words into a new context, for example, 'downpress' for oppress” (Pollard “The Social History of Dead Talk,” cited in Hickling and Griffith, “Clinical Perspectives on the Rastafari Movement,” 50).
} 
manifest or freedom of will. ${ }^{16}$ Rastafarl's apparent rejection of traditional theodicies highlights and challenges theologies of suffering, which appear removed from the concrete circumstances within which they were originally framed. Indeed, with their present time focus, Rasta theodicies may well be a kind of realised eschatology.

\section{Articulating Rasta theodicies}

This section maintains that the theological perspectives of RastafarI continue to be under-researched in the Caribbean context with perhaps more attention being paid to their contributions to the racial, musical and linguistic traditions of the region. In particular, there has been little sustained theological reflection on Rasta theologies of suffering, especially theodicy (Blatter, "Chunt Down the Babylon" is the noted exception. Jagessar, "The Sacred in Caribbean Literature" also does a brief reflection on RastafarI theodicy in literature as counter to the western theodicy.). The lack of discourse on the Rasta theodicy may be because theodicy is not as clearly articulated as other elements of the Rastafarian belief system such as the divinity of Emperor Haile Selassie. This muted articulation is impacted by the significant diversity of belief and theology among RastafarI mansions and individuals concerning core doctrine and practice, even dreadlocks. ${ }^{17}$ So the purpose and meaning of suffering among Rasta would be no less diverse even as it may not be fully or well-articulated. Indeed, Owens notes that "there are several more or less complementary doctrines which are put forth to explain their painful circumstances." 18 Therefore, to approach RastafarI theodicies requires a careful assemblage of perspectives from within the literature. The attempt to do so gives heuristic coherence to a complex reality.

\section{Suffering and evil in Caribbean theology}

At the same time, "the problem of suffering, evil and the role of a good God need re-working in Caribbean theology." ${ }^{19}$ Recognising this, this exploration takes as its starting point two prior theological pieces, which attempt to wrestle with the problem of evil and suffering from a Caribbean perspective: "Just Desert or Just Deserts?: God and Suffering in these Perilous Days"20 and "The Wages of (Sin) is Babylon: Rasta Versus Christian Religious Perspectives of Sin;"21 the former reflection highlights the insufficiency of traditional theodicy to answer the question: "if God is good, why does evil exist?" It concludes that no one answer can do justice to the many dimensions of the question. In that regard, the author (Perkins) argues for attention to the important "answer" that the radical suffering perspective offers to the discussion ${ }^{22}$ (Similarly, Indian theologian Sarah Anderson Rajarigam emphasises divine suffering or theopathos as the response to radical suffering. She frames theopathos not just as an option within theodicy but as an alternative to theodicy, which she calls "the spoilt child of enlightenment that self-destructively craves for theoretical and philosophical remedies for radical human suffering."23).

In the second exploration, Perkins explicates a particular Rasta understanding of sin and evil, which are important elements of any theodicy. ${ }^{24}$ For Rasta, sin is tri-dimensional-personal, inherited and

16 Jagessar, "The Sacred in Caribbean Literature: A Theological Conversation,” 15-26.

17 Barnett, "The Many Faces of Rasta," 67-78.

18 Owens, Dread, 192.

19 Jagessar, "The Sacred," 42.

20 Perkins, "Just Desert or Just Deserts?: God and Suffering in these Perilous Days," 179-92.

21 Perkins, "The Wages of (Sin) is Babylon: Rastafari Versus Christian Religious Perspectives on Sin,” 239-52.

22 Perkins, “Just Deserts or Just Desert?".

23 Anderson Rajarigam, “Theopathos: A Post-Patriarchal Approach to Theodicy in Black, Dalit and Jewish Holocausts,” 27. 
corporate. Sin in its corporate or social dimension is the most salient as it is moral evil - a rejection of Jah's will - which leads to the oppression of Jah's people and enormous amounts of suffering [sufferation]. Many Rastas respond to this by evoking the power of words to chant down the Babylon Shitstem or even embark on revolution against it. In contrast, for other Rastas, the Rastaman has a duty to respond to suffering patiently, knowing that Jah is in charge and will bring vindication in his own time. Clearly, there is a tension between the required responses to corporate $\sin /$ evil - revolutionary chanting down which has the power to destroy the Babylon Shitsem or patient waiting on Jah. It is not a tension easily resolved.

\section{Theologies of suffering for the Caribbean}

James Keenan, American catholic theologian, citing Eric Cassell, describes suffering as "the distress brought about by the actual or perceived impending threat to the integrity or continued existence of the whole person." 25 Suffering is engendered by the loss of the ability to pursue one's purpose, which entails a good that is of significance in life. The loss of such a good results in a diminishing of well-being and relatedness to others. "Thus, when people suffer, they find themselves marginalized from those who enjoy the very goods they have lost or were hoping would be theirs." ${ }^{26}$ Suffering calls out for meaning and God is called upon to give answer, as the biblical Book of Job illustrates. One way to render suffering meaningful is to trace its genesis to some "order of reality" where events and processes can be held responsible for suffering. ${ }^{27}$ In the religious sphere, this meaningfulness is sought in the permissive will of the divine who allows suffering for a reason.

One example of a traditional Christian attempt to render suffering meaningful is Jamaican Marie Reynolds. Reynolds argues that "a theology of suffering and a theology of poverty are vitally needed to address these realities of Caribbean experience," which is rife with suffering and poverty. ${ }^{28}$ She questions, in this regard, "What is God's message to those who are in the throes of suffering and poverty, and how may God be speaking through them? What does such an existence say concerning the nature and character of God [i.e., theodicy]?"29 Reynolds then presents a typical conservative answer to the theodicy question. Using a paraphrase and gloss on several verses from various books of the Hebrew Bible, she argues for God's dominion over the "kingdoms of the world."

God is therefore able to use for His purposes what human beings intend for evil: Hence, even though the Caribbean nation is rooted in the brutality of slavery and the oppression of colonisation, God can use the people thus gathered for His good purpose. Perhaps God would use this region to demonstrate the eschatological throne room wherein people from every nation, tongue and tribe will gather to honor and glorify His name in a celebratory hymn of praise. ${ }^{30}$

God can use the melting pot of the Caribbean created by the brutality of slavery to demonstrate that, in the end times, a similar diversity of people will be gathered together worshipping God in the heavens. Reynolds, simultaneously, holds that God scattered the peoples of the Caribbean into slavery when they flouted God's cultural or dominion mandate but, nonetheless, still created with them a beautiful mosaic which prefigures the eschatological throne room. What is lost in such a discourse is that it in effect blames the ancestors of Afro- and Indo-Caribbean peoples for their oppression and the current condition of their descendants (merited inherited punishment). This is not a singular belief as many Christians and some

24 Perkins, "The Wages of (Sin)."

25 Keenan, Moral Virtue: Lessons and Texts from the Catholic Tradition, 59.

26 Ibid., 60.

27 Shweder et al., "The 'Big Three' of Morality (Autonomy, Community, Divinity) and the 'Big Three' Explanations of Suffering.” 119-69, 120.

28 Reynolds, “Toward a Caribbean Evangelical Theology,” 24-33, 28.

29 Ibid., 28.

30 Ibid., 28. 
Rastas hold a similar perspective, as is discussed below. Slavery and oppression are therefore the justifiable consequences of the actions and activities of the children of Ham. ${ }^{31}$ This "explanation" leaves open the question of innocent suffering - how to make sense of the suffering being experienced by the descendants of the formerly enslaved and indentured Caribbean people. Reynolds does not face that question directly but affirms God as the sovereign and author of all nations and so he brings them together to deliver their cultural mandate (redemptive suffering), regardless of the circumstances. Unfortunately, this explanation lets the oppressors as well as individual wrongdoers off the hook while engaging in victim blaming. It cannot effectively deal with radical suffering.

\section{Concerns with traditional theodicies}

Keenan identifies the deepest concern of the religious response to suffering as the desire to overcome it. He acknowledges that "there has been an excess of suffering and evil in [human history]." 32 This "excess of suffering" is highlighted by Anderson Rajarigam as she explores the experiences of Jews, Blacks and Dalits. In the face of such excess, Keenan argues that suffering remains incomprehensible and impenetrable for Christians. He therefore attempts to correct what he identifies as the false impression promoted by Christians that suffering is the expression of the will of a loving God. Keenan presents redemptive suffering to help another as a primary model of divine love as the counter perspective. Even so, Keenan believes that there is too much trust in the distinction between merited and unmerited suffering.

Anderson Rajarigam argues that contemporary theologians have shifted away from a focus on natural evil to moral evil, which places evil and the suffering it engenders in a more political framework. In addition, she argues that contemporary theologians have avoided the pitfalls of theodicy by their focus on divine suffering or theopathos. She frames theopathos not just as an option within theodicy but as an alternative to theodicy. Anderson Rajarigam further notes that, given the highly contextual nature of theological reflections, it is possible to identify traditional theodicy as gendered and thus deeply reflective of male interests and conditioned by male experiences. Such theodicies are riven through with questions of power, yet, like Keenan, she does not believe God's power and goodness can be justified as compatible with evil.

In a similar vein, Jamaican-descended British-born theologian Delroy Hall too raises "the uncertain nature of theodicy" from which arises questions regarding suffering, God's justice and the treatment of people created in the image of God..$^{33}$ In particular, Hall maintains that the subject of theodicy raises problematic questions and concerns for Black people in Britain and elsewhere. Hall therefore identifies a racial politics embedded in traditional theodicies. He goes on to reframe theodicy using the motif of crucifixion, as highly meaningful to Afro-descended British people.

Anderson Rajarigam, in contrast, in launching a critique of theodicy as patriarchal, maintains that "while the reality of evil is extremely conscious of both gender and race the same cannot be said of suffering." ${ }^{34}$ According to her, in radical suffering, the loss of human dignity is so profound that both "race and gender disappear and we stand as helpless beings." ${ }^{35}$ Furthermore, to talk about gender in suffering is to see suffering as less than dehumanising since such features of our humanity remain intact. Not to recognise how radically dehumanising suffering is, is to fall into the trap of the various theodicies she rejects as minimising the reality of radical evil brought about by human agency or anthropodicy. This

31 The story of the curse of Ham in Genesis 9 is well-known as the source of validation of enslavement of Africans who are identified with the descendants of Noah's cursed son Ham. It has been treated in traditional media. See Felicia R. Lee, From Noah's Curse to Slavery's Rationale.

32 Keenan, Moral Virtue, 61.

33 Hall, "The Middle Passage as Existential Crucifixion," 46.

34 Anderson Rajarigam, “Theopathos,” 41.

35 Ibid., 41. 
stance has deep resonances with a RastafarI theology of suffering even as that particular theodicy, which like Hall, is highly conscious of race and its impact on the suffering of many. In so doing, even as it is necessary to acknowledge how abject radical suffering renders the victim, it continues to find race meaningful in both excessive suffering and evil. Race is the reason for radical suffering even if such suffering has the potential to deracinate having reduced the sufferah to the abject. At the same time, it is not to be overlooked that Rasta itself is deeply patriarchal and so gives expression to gendered notions that impact ways of theologising that are exclusive of women, hence the reference to the Rastaman throughout. This is an area of significance for further theological reflection, particularly as it relates to human dignity and the possibilities of salvation.

\section{Rastafarl theologies of evil and suffering}

\subsection{Shaped by suffering}

A main question of theodicy concerns the presence or absence of God in a situation of extreme suffering. ${ }^{36}$ Jamaican cultural critic Rex Nettleford maintains that RastafarI theology goes beyond narrow theological hermeneutics and exegesis, which can be considered to be "Christian-specific and predetermined in that tradition." ${ }^{37}$ Indeed, Jack Johnson-Hill, drawing on the poetry of RastafarI, argues like Edmonds and Owens that the self-consciousness of divine indwelling - I-n-I - has been shaped fundamentally by suffering in the Afro-Jamaican context. ${ }^{38}$ So Rastafarl's own sense of divine reality, while being largely rooted in the Hebrew Scriptures, is as much supported by "the historical experience of a sustained period of severance and suffering, followed by continuing psychic exile, alienation, and anomie." 39 "Rastafarians are keenly conscious of the intensity of the suffering going on in their midst," ${ }^{40}$ which calls out for response and explanation. Suffering is explained by Rastas in several more or less complementary, multifaceted even contradictory accounts: historical but also personal; systemic but individual; and eschatological but current and concrete. This experience of personal and corporate suffering does not go unreflected upon, clearly, even as it has not been fleshed out in a singular coherent, sustained theological discourse.

\subsection{Greed, racial and imperial injustice}

American George Eaton Simpson, one of the earliest researchers of RastafarI, illustrates how the question of divine absence/permissiveness in the face of suffering is posed by a Rastaman in the concrete circumstances of his experience as an imperial subject: "Where was God when the white man was raping India, Egypt and other countries?” 41 Simpson's RastafarI informant immediately adds to his question a

\footnotetext{
36 Perkins, "Just Deserts or Just Desert?"

37 Nettleford, “Discourse on Rastafarian Reality,” 313.

38 Johnson-Hill, I-Sight: The World of Rastafari-An Interpretive Sociological Account of Rastafarian Ethics, 1995.

39 Nettleford, "Discourse on Rastafarian Reality,” 313.

40 Owens, Dread, 192.

41 Simpson, "Political Cultism in West Kingston, Jamaica," 142.
} 
statement of faith: "Haile Selassie is Jesus Christ reincarnated." ${ }^{22}$ This affirmation ${ }^{43}$ - not condemnation appears to sidestep the concrete question of such colossal unmerited suffering engendered by racial and imperial injustice. Simpson, therefore, maintains:

Ras Tafarism provides explanations of their plight to economically disadvantaged people. Poverty, misery, and degradation are due to the selfishness, cruelty, and wickedness of the white man and the black traitor. This dogma, together with the myth of the soon-to-be-realized beautiful life in the Homeland, makes life more understandable and more endurable. In a negative sense, the Ras Tafari movement contributes to the continuation of existing economic institutions. While largely excluded from going economic enterprise. ${ }^{44}$

Sin and suffering result from the oppression perpetrated by the White race against the Black race. It results from acts of greed and selfishness coupled with cruelty with the result being a kind of an economic impotence among the dispossessed.

The Rasta classic, Living Testament of Rasta-for-I, by Ras-J-Tesfa, also presents greed as central to the origin myth of why suffering is the lot of Jah's Children. In echoes of the Genesis story, Ras-J-Tesfa retells a myth of paradise, wherein African man and "womb-man" walked in the light of Jah and created great cities. It was the proud and arrogant rulers identified with Alexander of Macedon [clearly a representation of the White race] who, through their greed, caused suffering to be inflicted on these children of Jah. He is clear that suffering is man-made and the result of corporate greed inflicted on the descendants of the original people even till today. Such suffering is not the will of Jah but was due to the greed of men coupled with the "sins of the forefathers" who were guilty of betrayal of their Black brothers and sisters. ${ }^{45}$

\subsection{Patient I-durance}

Sheila Kitzinger, another early pioneer researcher, concurs that Rastas identify the forces of evil with "the White race and the Black people who cooperate with them, oppose them at every turn." 46 Rastas "[expect] the eventual overthrow of White power as prophesied in the Bible: There is no throne for the Anglo-Saxon white people and their puppets, they must come down and sit in the dust, on the ground; there is no throne for them.”47 This affirmation is captured in songs such as Bob Marley's "Rasta Man Chant," which declares, "Babylon you throne gone down," an eschatological declaration encompassing the already and the not yet. Something of this end time-but-now expectation is evident in Kitzinger's reporting of her experience among the early Rastas:

One has only to ask a Rasta how he is today to bring forth an immediate outburst about the vengeance of the Lord, the present victimisation and penalisation, the evil of Sodom and Gomorrah, of Sir Alexander Bustamente ${ }^{48}$ [sic] and the police, and the desolation that awaits. ${ }^{49}$

42 Simpson, "Political Cultism," 142.

43 Furthermore, this affirmation is counter assertion, a claim to dignity and power in the face of rejection in a Babylonian world. See J. Richard Middleton, “Identity and Subversion in Babylon: Strategies for 'Resisting Against the System' in the Music of Bob Marley and the Wailers.” In Religion, Culture and Tradition in the Caribbean, edited by Hemchand Gossai and Nathaniel Samuel Murrell. Houndsmills: Macmillan Press, 2000, 181-205.

44 Simpson, "Political Cultism," 146.

45 Owens, Dread, 294.

46 Kitzinger, "Protest and Mysticism: The Rastafari Cult of Jamaica," 241.

47 Ibid., 241.

48 Alexander Bustamante, former prime minister of Jamaica, who ordered that Rastas be brought in "dead or alive," in response to an incident in Coral Gardens, Montego Bay, in 1963, in which a bearded man was accused of killing a man. This led to the general persecution of Rastafarians. The misspelling of his name may well be deliberate, as Rastas use wordplay heavily to reframe reality and expose the truth often considered to be hiding behind a seemingly innocuous word.

49 Kitzinger, "Protest and Mysticism," 251. 
These imprecations against Babylon and its minions are not to be mistaken as a passive acceptance of the status quo, however. Such calls for vengeance are accompanied by powerful songs of resistance to "the cultural and political domination of the Babylonians," ${ }^{50}$ which can lead to further oppression. Indeed, according to Murrell,

\begin{abstract}
Rastas seek to reverse the Israelite's Babylonian experience by singing Hebrew songs as protest against Black people's oppression in "Babylon" with cool reggae revolutionary rhythms rather than military might. Psalm 137 thus becomes a call not to capitulate in silence to Babylon or assimilate its cultural values; not to wallow in the mire of hopelessness and selfpity or wish for the former days of the nation's glory; not to offer imprecations to a God who is not there for Rastas, silent, hidden (deus obsconditus), and indifferent to the people of African descent; but a militant song to rub Babylon's nose in the dust - to chant down Babylon in "ah ridim" - and effect social change..$^{51}$
\end{abstract}

For Simpson, the lack of a commitment to revolutionary change in the face of the expectation of Jah leading them to Zion makes RastafarI conservative and status quo preserving. This is a mistaken reading, as Owens would argue; on the contrary, this is an apparent endurance in the face of disadvantage and is directly related to Rastaman's theology of suffering. RastafarI are convicted that Jah is in charge and will act in his own time and his wisdom, as prophesied in the Scriptures. Change will happen in Jah's time, so the duty of the Rastaman is to wait for Jah's action, to "i-dure." This does not negate Jah's action being joined to those of his sufferah children, but, ultimately, Jah is in charge and leads the charge. Owens maintains that this is an eschatological stance which is borne out in the patience exhibited by Rastas in long hours of meditation and reasoning, willingness to work long hours for little remuneration or the readiness to drop everything to entertain a stranger or a friend. In tandem to such patient endurance, "Rastafari urged their fellow sufferers to eschew dependency and take responsibility for their liberation, which could only come through self-sufficiency." 52

\title{
6 Punishment for faithlessness
}

At the same time, in a parallel theodicy, similar to Marie Reynold's conservative theodicy, Jah's children are implicated in their own suffering. Indeed, Owens notes that, consistent with Judeo-Christian theodicy, Rastafarians maintain that Africans of the Diaspora had been taken into slavery and scattered by Jah for turning their backs on Jah (merited suffering). As discussed previously, this punishment is meted out to generations coming after (inherited unmerited suffering). This accords with Rasta's sense of justice, which sees each one paid according to his work. It is incumbent upon Rasta, therefore, as Owens contends, to "strive to be ever more faithful to their God, in the hope that he will release them from their torment and lead them to the New Jerusalem." ${ }^{33}$ Of course, this sense of just recompense is better applied individually and directly, and its corporate application expresses the solidarity between ancestors and descendants. However, it falls short in giving meaning to the radical suffering - whether individual or corporate that results from innocent suffering. Nonetheless, the advent of the Divine Emperor signalled forgiveness and expiation of sin. Consequently, the end of Rasta's suffering is near but not yet.

50 Murrell, “Tuning Hebrew Psalms to Reggae Rhythms: Rasta’s Revolutionary Lamentations for Social Change,” https:// crosscurrents.org/murrell.htm.

51 Murrell, "Tuning Hebrew Psalms to Reggae Rhythms.”

52 Cadence Wynter, “Rodney and Rastafari: Cultural Identity in 1960s Jamaica," 300-8.

53 Owens, Dread, 193. 


\subsection{Here and now theology}

The Church in particular comes in for harsh criticism from RastafarI as it is implicated for teaching the kind of theodicy that Simpson mistakenly identifies among the early proponents of RastafarI. Such a theodicy causes sufferahs to bear their suffering bravely because they "have a pie in the sky when they die," which Rhygin, the outlaw character played by Jimmy Cliff in the movie, The Harder They Come, scoffs at. Indeed, Rastafarians from very early railed against the impact of the teaching of the Church as a key aspect of the Babylonian system that has been responsible historically for various atrocities and continues to perpetrate such in its contemporary Euro-American manifestation. ${ }^{54}$ In response, some Rastas maintain a decidedly "here and now theodicy" which recognises and rejects the key form of suffering - "downpression" of Jah Children by Babylon and its agents. ${ }^{55}$

This here and now theodicy requires "maintaining an alternative consciousness and identity in the face of the dehumanising worldview of the dominant order." ${ }^{56}$ The alternative consciousness and identity appeal to historical memory, particularly a metanarrative of resistance to Babylon. In so doing, Rastas identify and challenge the political implications of traditional theodicies, which, as Anderson Rajarigam and others have demonstrated, are unable to treat with the memories and experiences of excessive suffering, especially among Africans and their sufferah descendants; traditional theodicies of unmerited suffering are, as such, rendered incoherent. Rastas reject such incoherent theodicies which can be shown to have political ideological implications as they impact the lives of those forced to the margins and the oppressed in a fashion that supports their continued subjugation (redemptive suffering) while leaving perpetrators and systems untouched.

\section{Doing good}

Such experiences of unmerited suffering are not a thing of the past; the rights of Rasta have been and continue to be violated, as is heard time and again in the powerful lyrics of Reggae and other forms of Jamaican popular music. When Rastas are persecuted for doing the good and the right, they experience unmerited suffering. ${ }^{57}$ Suffering can indeed be a consequence for doing good. The good man's suffering is caused by the evil powers of Babylon abroad in the world. This can perhaps be recast as redemptive suffering and this may be mirrored in the move, in some instances, to valorise the individual Rastaman as hero or prophet. ${ }^{58}$ Nonetheless, the response to such unmerited suffering has been seeming acceptance but also calls for revolution through the use of Word, Sound and Power. ${ }^{59}$ Nowhere, however, does the possibility of theopathos emerge as a fully formed doctrine.

\section{Learning from suffering}

Suffering does not therefore remain meaningless or opaque as some Rastas see suffering as a tool for learning, learning the truth about himself: "One would learn from suffering. It is a regenerating thing, you see. One would recognise what one is, who one is (Catman)."60 One such truth is that suffering is

54 Edmonds, "Dread 'I'."

55 Tesfa. Living Testamant of Rasta-for-I.

56 Middleton, "Identity and Subversion," 182.

57 DeCosmo, "Religion and Revolution in the Lyrics of Bob Marley," 13.

58 Broek, "The Rastafarian: From Pariah to Hero in Jamaican Literary Discourse from the 1950s to the 1980s," 39-48.

59 Chevannes, Rastafari: Roots and Ideology (Utopianism and Communitarianism).

60 Owens, Dread, 193. 
inevitable for Children of Jah - Oh Sufferah Children. The same forces that arrayed themselves against the Emperor also persecute his children who are marked by this suffering. Perhaps there is an implicit ontology that marks out Rastas as inherently sufferahs. Such suffering is meaningful as only suffering children can truly know Jah. "[T]he people that is of the lineage of Jah is always a suffering people" (Teddy). ${ }^{61}$ Ironically, this personal current in the Rasta theologies of suffering echoes the traditional theodicies of merited suffering and so fall prey a similar critique concerning the incoherence of traditional theodicies and radical suffering.

\section{Some concluding thoughts}

Blatter makes the bold claim that the Rasta theodicy is unique as it does not legitimise or provide meaning for the social injustices they face; rather it socialises Rasta to reject the status quo, oftentimes with the power of words, while proposing an alternate vision for society. This is expressed through the powerful Reggae rhythms through which Rastas "chant down Babylon" and "sight-up a new Jerusalem - Ethiopia." Blatter's claim does not stand up to scrutiny, given the direction of modern theodicies, which, as Anderson Rajarigam demonstrates, have maintained a focus on moral evil, theopathos and anthropodicy. This emphasis on both the incompatibility of traditional theodicies with God and the recognition of human, especially corporate responsibility for suffering is significant to Rasta's rejection of theodicy, however. Rasta reflections on suffering, however, have not completely escaped the consternations of traditional theodicies, even as they very contextually wrestle with the human causes of excessive suffering, particularly in its historical corporate or systemic form.

There is something to be said for the way radical or excessive suffering strips a person of their very human dignity without losing sight of the kinds of suffering that result from social injustice that are aimed at groups of persons - Black, female, poor and Rasta. In particular, Rasta theodicies could further bear sustained reflections on a theopathos as they grope after the meaningfulness of excessive suffering, which continues to be the lot of Rastas. Doing so may prove difficult, however, as Jah RastafarI is "ever living, ever faithful, ever sure" and apparently impassible. Importantly, the question of the effectiveness of the RastafarI challenge to mainstream society is debatable, especially given the fact that Rasta has become institutionalised within Jamaican society; this has led to them being marginalised as a force for societal change. While they "evolved from the underclass" to become "vehicles of protest," having been largely coopted, they are less influential agents of change. ${ }^{62}$ Indeed, Miller maintains that "in the process, the change agent has itself been changed.”63

\section{References}

Anderson Rajarigam, Sarah. "Theopathos: a Post-patriarchal Approach to Theodicy in Black, Dalit and Jewish Holocausts." Voices from the Third World XXVli:1 (2004), 22-52.

Barnett, Michael. "The many faces of Rasta: Doctrinal Diversity within the Rastafari Movement." Caribbean Quarterly 51:2 (2005), 67-78.

Blatter, Emily. "Chant Down Babylon: The Rastafarian Movement and Its Theodicy for the Suffering." Verge: The Goucher Journal of Undergraduate Writing 5 (2008), 1-46. https://blogs.goucher.edu/verge/files/2016/01/Blatter.pdf.

61 Owens, Dread, 193.

62 Miller, "The Rastafarian in Jamaican Political Culture,” 117.

63 Ibid., 117. 
Broek, Aart. "The Rastafarian: From Pariah to Hero in Jamaican Literary Discourse from the 1950s to the 1980s." In Breaking Down Binaries: Tidal Shifts in the Study of the languages, literatures and cultures of the Greater Caribbean 2, edited by Nicholas Faraclas et al., 39-48. University of Puerto Rico, 2018.

Chevannes, Barry. Rastafari: Roots and Ideology (Utopianism and Communitarianism). NY: Syracuse University Press, 1994.

DeCosmo, Jan. "Religion and Revolution in the Lyrics of Bob Marley." Caribbean Studies Assn. Conference, Merida, Yucatan, Mexico, May 1994.

Edmonds, Ennis B. “Dread 'l' in-a-Babylon: Ideological Resistance and Cultural Revitalization.” In Chanting Down Babylon: The Rastafari Reader, edited by Nathaniel Samuel Murrell, William David Spencer, Adrian Anthony McFarlane, 23-35. Kingston: Ian Randle Publishers, 1998.

Ehrengardt, Thibault. Gangs of Jamaica: The Babylonian Wars. Dread Editions/Jamaica Insula \#05, 2012/2013.

Felicia, R. Lee. From Noah's Curse to Slavery's Rationale. The New York Times, November 1, (2003). https://www.nytimes.com/2003/11/01/arts/fromnoah-s-curse-to-slavery-s-rationale.html.

Hall, Delroy. "The Middle Passage as Existential Crucifixion.” Black Theology 7:1 (2009), 45-63.

Hickling, Frederick W. and Griffith, Ezra E. H. "Clinical Perspectives on the Rastafari Movement." Hospital and Community Psychiatry 45:1 (1994), 49-53.

Jagessar, Michael N. "The Sacred in Caribbean Literature: A Theological Conversation." In Reading Spiritualties: Constructing and Representing the Sacred, edited by Dawn Llewellyn and Deborah F. Sawyer, 15-26. Hampshire: Ashgate Publishing, 2008.

Johnson-Hill, Jack A. I-Sight: The World of Rastafari - An Interpretive Sociological Account of Rastafarian Ethics. Lanham, MD: Scarecrow Press, 1995.

Keenan, James F. Moral Virtue: Lessons and Texts from the Catholic Tradition. New York: Rowman and Littlefield, 2017.

Kitzinger, Sheila. "Protest and Mysticism: The Rastafari Cult of Jamaica." Journal for the Scientific Study of Religion 8:2 (1969), 240-62.

Miller, Marian. "The Rastafarian in Jamaican Political Culture.” The Western Journal of Black Studies 17:2 (1993), 112-7.

Murrell, Nathaniel Samuel. "Tuning Hebrew Psalms to Reggae Rhythms: Rasta's Revolutionary Lamentations for Social Change." Cross Currents 50:4 (Winter 2000-2001). https://crosscurrents.org/murrell.htm.

Nettleford, Rex. "Discourse on Rastafarian Reality." In Chanting Down Babylon: The Rastafari Reader, edited by Nathaniel Samuel Murrell, William David Spencer, Adrian Anthony McFarlane, 311-25. Kingston: Ian Randle Publishers, 1998.

Owens, Joseph. Dread: The Rastafarians of Jamaica. Kingston and London: Heineman Educational Books Ltd, 1976.

Perkins, Anna Kasafi. "The Wages of ( $\mathrm{Sin}$ ) is Babylon: Rastafari Versus Christian Religious Perspectives on Sin." In Rastafari in the New Millennium: A Rastafari Reader, edited by Michael Barnett, 239-52. New York: Syracuse University Press, 2012.

Perkins, Anna Kasafi. “Just Desert or Just Deserts?: God and Suffering in these Perilous Days.” Black Theology 14:3 (2016), 179-92.

Pollard, V. "The Social History of Dread Talk." In Studies in Caribbean Languaged, edited by ID Carrington. Port of Spain, Trinidad: Society for Caribbean Linguistics, 1983.

Reynolds, Marie. “Toward a Caribbean Evangelical Theology.” Binah 1 (1996), 24-33.

Shweder, Richard A., Much, Nancy C., and Mahapatra, Manamohan, and Park, Lawrence. "The 'Big Three' of Morality (Autonomy, Community, Divinity) and the 'Big Three' Explanations of Suffering. In Morality and Health, edited by Allan M. Brandt, Paul Rozin, 119-69. New York: Routledge, 1997.

Simpson, George E. "Political Cultism in West Kingston, Jamaica." Social and Economic Studies 4:2 (1955), 133-49.

Tesfa, Ras-J. Living Testamant of Rasta-for-I. Greenfield: Lincia Graphics/L, 1980.

Wynter, Cadence. "Rodney and Rastafari: Cultural Identity in 1960s Jamaica." In Rastafari in the New Millennium, edited by Michael Barnett, 300-8. New York: Syracuse University Press, 2012/2014. 